\title{
Adding Value? EU Governance of Organ Donation and Transplantation
}

\section{Abstract}

This article examines recent developments in EU governance of organ donation and transplantation, focusing on an analysis of the Commission's action plan and the proposed Directive. While the aims of the plan are laudable, a number of concerns remain with respect to the timetable for the plan and the adoption of the Directive, as well as the management of ethical and risk issues. In the final analysis, the added value of EU governance initiatives in the field is likely to be measured by the extent to which they successfully address the ongoing problem of organ shortage in Member States.

Keywords

organs; organ donation; organ transplantation; governance; European Union (EU); risk regulation; organ procurement; organ shortage

\section{Introduction}

There has been an increasing level of policy activity at EU level in recent years in the field of organ donation and transplantation. In December 2008, the European Commission (Commission) published a six-year action plan and argued for the added value of EU action on a number of grounds, including the likelihood of an increase in the rate of organ donation through the sharing of best practices, best models and expertise; the creation of an EU-wide risk regulation regime which would establish basic quality and safety requirements in organ donation and transplantation, as well as reduce risks posed to donors and recipients; and increased cross-border exchange of organs, which was likely to be of particular benefit for smaller Member States with limited donor pools, as well as for difficult-to-treat or urgent patients. ${ }^{1}$ The Commission identified three main challenges in its action plan: increasing organ availability; enhancing the efficiency and accessibility of transplantation systems; and improving the quality and safety of organs for transplant. Ten priority actions were identified in order to address

1) EUROPA. Press Release. Q \& A: EU Directive and Action Plan on Organ Donation and Transplantation. Memo/08/774 (Brussels: 8 December 2008), 2-3. Retrieved 19 November 2009. http://europa.eu/rapid/ pressReleasesAction.do?reference=MEMO/08/774\&format=HTML\&aged=0\&language=EN . 
these challenges. ${ }^{2}$ Accompanying the publication of the action plan by the Commission was a proposal for a framework Directive which would establish a risk regulation regime in relation to human organs intended for transplantation (proposed Organs Directive). ${ }^{3}$

The EU's power to take action in the field of organ donation and transplantation is derived from the public health competence set out in Article 168 TFEU (ex Article 152 EC). There are a number of components to action that may be taken at EU level under this Article, which is based on shared competence with Member States in relation to 'common safety concerns in public health matters'. ${ }^{4}$ First, emphasis is placed on encouraging cooperation between Member States in the areas referred to in the Article and, if necessary, to lend support to their action. This specifically includes encouraging cooperation to improve 'the complementarity of health services in cross-border areas'. In this regard, the Commission may 'in close contact' with the Member States take any useful initiative to promote such coordination, in particular initiatives aimed at the establishment of guidelines, indicators, the organisation of exchange of best practice, and the preparation of the necessary elements for periodic monitoring and evaluation'. ${ }^{5}$ Second, the European Parliament and Council are empowered to adopt 'measures setting high standards of quality and safety of organs', although 'these measures shall not prevent any Member State from maintaining or introducing more stringent protective measures'. ${ }^{6}$ Finally, it is emphasised that any measures so adopted 'shall not affect national provisions on the donation or medical use of organs."

The aim of this article is to examine recent developments in EU governance of organ donation and transplantation, focusing on an analysis of the Commission's current action plan and the proposed Organs Directive. While the aims of the plan are laudable, I argue that a number of concerns remain with respect to the timetable for achieving its objectives, as well as the management of ethical and risk issues. Nevertheless, it should be seen as a welcome development, particularly if it results in increasing organ availability in Member States. A further issue regarding timing is raised by the publication of the proposed Organs Directive. Given the ambitious objectives set out in the plan, the differing levels of infrastructural development of organ procurement and transplantation, and limited national administrative and personnel resources, I question whether it may be more appropriate to focus in the short term on action that is most likely to bring

\footnotetext{
2) Commission of the European Communities. Communication from the Commission. Action plan on Organ Donation and Transplantation (2009-2015): Strengthened Cooperation between Member States. COM (2008) 819/3. Brussels, 8.12.2008, p. 2.

3) Proposal for a Directive of the European Parliament and of the Council on standards of quality and safety of human organs intended for transplantation. COM (2008) 818 final. Brussels, 8.12.2008.

4) Article 4(2)(k) TFEU.

5) Article 168(2) TFEU.

a) Article 168(4)(a) TFEU.

7) Article 168(7) TFEU.
} 
about efficient and effective organ procurement at national level. The adoption of 1 an Organs Directive could then be re-considered at regular intervals as an option 2 in the medium to long term. In order to consider these questions in more detail, 3 the Commission's action plan is examined in detail in the first section of the 4 paper. Thereafter, key aspects of the proposed Organs Directive are analysed. The 5 final section examines a number of concerns regarding the use of expertise, as well 6 as the management of ethical and risk issues, that require further consideration in 7 the context of adding value to EU governance in the field.

\section{Emerging EU Governance on Organ Donation and Transplantation}

\subsection{Early Initiatives}

A treaty competence to adopt minimum harmonisation measures setting standards for quality and safety in relation to blood, tissue and organs was created through the Treaty of Amsterdam which came into force in $1999 .{ }^{8}$ This subsequently led to a series of governance initiatives which resulted in the adoption of the Blood Directive in January $2003^{9}$ and the Tissues and Cells Directive in $2004 .{ }^{10}$ It was acknowledged by the Commission at an early stage, however, that a different approach was required in the case of organ donation and transplantation to that of blood and tissues/cells. This was attributable primarily to the differential risk-benefit analysis that was required in the field, against a background of persisting organ shortage at national level. ${ }^{11}$

A series of EU-sponsored conferences were organised to examine issues involving organ donation and transplantation between 2000 and $2003 .{ }^{12}$ In 2003, a strong political impetus was provided for further work in the field, with the Greek Presidency identifying the need to combat organ trafficking as a priority. Subsequently, the Italian Presidency convened an expert conference to discuss quality and safety issues in organ donation and transplantation. The conclusions from

\footnotetext{
8) Article 152(4)(a) EC (now Article 168(4)(a) TFEU).

9) Directive 2002/98/EC of the European Parliament and of the Council of 27 January 2003 setting standards of quality and safety for the collection, testing, processing, storage and distribution of human blood and blood components and amending Directive 2001/83/EC, OJ L 33, 8.2.2003.

10) Directive 2004/23/EC of the European Parliament and of the Council of 31 March 2004 on setting standards of quality and safety for the donation, procurement, testing, processing, preservation, storage and distribution of human tissues and cells. OJ L 102, 7.4.2004.

11) Commission of the European Communities. Commission Staff Working Document: Accompanying Document to the Communication from the Commission to the European Parliament and Council: Organ Donation and Transplantation: Policy Actions at EU Level: Impact Assessment. SEC (2007) 704. 30.5.2007, 4, 6 .

12) E. Fernandez-Zincke, Transcript of Evidence. 22.11.2007. House of Lords European Union Committee, Increasing the Supply of Donor Organs within the European Union, Volume II: 17th Report of Session 2007-08, (HL Paper 123-II) (London: The Stationery Office, 2008), 2-3.
} . .

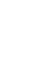
列 列

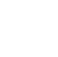
(1) (3)

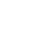

(7)

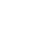

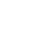
年 
the conference described organ shortage and organ trafficking as the main priorities in the field and underlined the fact that quality and safety aspects needed to be situated within a framework which took account of supply and demand issues involving organs. ${ }^{13}$ Various empirical and scientific research projects were subsequently commissioned and an extended consultation process was conducted by the Commission with relevant experts and stakeholders to identify areas of concern, as well as levels of support for various policy options.

\subsection{The Commission's Communication of May 2007}

Following the response received to its initial consultation process, the Commission published an initial Communication in May 2007 setting out a proposed action plan in the field. ${ }^{14}$ This was accompanied by an Impact Assessment which provided a detailed explanation, as well as rationales, for its plan. ${ }^{15}$ The Commission stated in this initial action plan that it intended to focus on strengthening cooperation between Member States and identified what it considered to be the main challenges in organ donation and transplantation within the EU. It confirmed that it intended to draw on the Open Method of Coordination (OMC) in order to identify common objectives for which it was agreed an EU response was needed; to develop both qualitative and quantitative indicators from which benchmarking could be undertaken; and to facilitate the sharing of relevant information on a regular basis in order to foster best practice in areas where this had been identified as necessary. Such areas included organisational models for organ donation, procurement and exchange, the promotion of an EU donor card, and access to Member State transplant facilities by non EU-citizens. Although organ trafficking was acknowledged to be a matter that warranted further consideration, it was not identified as a priority action. ${ }^{16}$

The feedback from the European Parliament (Parliament) and the Council on the Commission's initial action plan was largely positive. The Council emphasised, however, that the Commission needed to work closely with Member States and to proceed on the basis of 'agreed objectives and priorities'. ${ }^{17}$ In addition, the Parliament emphasised that the Commission should ensure that the implementa-

\footnotetext{
13) Commission of the European Communities. Impact Assessment. 30.5.2007, supra, n. 11, 6.

14) Commission of the European Communities. Communication from the Commission to the European Parliament and Council: Organ Donation and Transplantation: Policy Actions at EU Level. COM (2007) 275 final. 30.5.2007.

15) Commission of the European Communities. Impact Assessment. 30.5.2007, supra, n. 11.

16) Commission of the European Communities. Communication. 30.5.2007, supra, n. 14, 8-11.

17) Council of the European Union, Press Release: 2837th Council Meeting: Employment, Social Policy, Health and Consumer Affairs (16139/07 (Presse 284). 5-6.12.2007. Retrieved 17 November 2009. http:// register.consilium.europa.eu/pdf/en/07/st16/st16139.en07.pdf; Approved Draft Conclusions on Organ Donation and Transplantation prepared by the Permanent Representatives Committee of the Council of European Union (15332/07). 16.11.2007. Retrieved 17 November 2009.

http://register.consilium.europa.eu/pdf/en/07/st15/st15332.en07.pdf.
} 
tion of the action plan would not create 'an additional administrative burden for 1 Member States or service providers', or would otherwise result in requirements 2 that could result in a decrease in the number of potential or actual donors. ${ }^{18} \quad 3$

The feedback received from national experts and stakeholders was also broadly 4 supportive in principle. ${ }^{19}$ Concern was expressed by a number of experts, how- 5 ever, about the use of OMC to implement the action plan, on the grounds that it 6 was likely to contribute to an unwanted administrative burden at national level. 7 It was suggested that if OMC was to be used, then it needed to be specifically 8 tailored to the field, as well as being highly flexible. ${ }^{20}$ Despite the concerns 9 expressed by experts, its use is supported by both the Commission as well as 10 under Article 168(2) TFEU. The use of OMC has grown in popularity across a 11 range of policy sectors since its endorsement by the European Council at the 12 Lisbon Summit of 2000. It is said to permit a more flexible and participatory 13 approach to the formation of policy, and contrasts with the traditional command 14 and control models which have been more commonly employed at EU level. ${ }^{21} \quad 15$ Evidence of its growing influence in EU policy-making processes is revealed in 16 the Commission's active promotion of the methodology for developing organ 17 donation and transplantation policy, and it marks a clear change in approach 18 from that taken in relation to earlier governance initiatives involving blood and 19 tissues/cells. ${ }^{22}$ Although it is early days yet, it remains to be seen how effective 20

18) European Parliament. Resolution on Organ Donation and Transplantation: Policy Actions at EU Level, 22 April 2008 (P6_TA_PROV(2008)0130). Retrieved 17 November 2009 www.europarl.europa.eu/ sides/getDoc.do?pubRef=-//EP//TEXT+TA+P6-TA-2008-0130+0+DOC+XML+V0//EN.

19) Commission of the European Communities. Key Stakeholders Meeting on Organ Donation and Transplantation: Summary Report. Brussels, 19 February 2008. Retrieved 17 November 2009 http://ec.europa. eu/health/ph_threats/human_substance/documents/ev_20080219_mi_en.pdf.

20) Commission of the European Communities. 2nd National Expert Meeting on Organ Donation and Transplantation at Community Level: Summary Report. Brussels, 20 November 2007. SANCO C6 (2008) 360020/ EFZ/ci), 7. Retrieved 17 November 2009 http://ec.europa.eu/health/ph_threats/human_substance/events_ organs_en.htm.

21) S. Borrás, \& K. Jacobsson, (2004), "The Open Method of Coordination and New Governance Patterns in the EU", Journal of European Public Policy 11(2) (2004), 188-189; T. Hervey, "The European Union's Governance of Health Care and the Welfare Modernization Agenda", Regulation \& Governance 2(1) (2008), 103.

22) Notwithstanding its growing institutional popularity at EU level, there has been much academic debate about the effectiveness of OMC processes. There is little published empirical research to substantiate its effectiveness in either engendering consensus in a given policy area at EU level, or in facilitating horizontal or vertical policy transfer or organisational learning. Concerns have also been raised about the extent to which OMC actually facilitates greater participation in EU decision-making processes in practice. Participation requires being able to access and respond to Commission working documents, background knowledge in relation to issues under discussion, and being able to be physically present at meetings which are regularly held in Brussels. This limits the field of potential participants in a given policy area, and the evidence available to date is that the promise of OMC as an instrument for enhancing participatory governance at EU level has not been realised (see J. Zeitlin, "Social Europe and Experimentalist Governance: Towards a New Constitutional Compromise" in G. de Búrca, (ed.), EU Law and the Welfare State: In Search of Solidarity (Oxford: Oxford University Press, 2005), pp. 218, 227-228; E. Szyszczak, "Experimental Governance: The Open Method of Coordination", European Law Journal, (1) 3 (1) (1) 8 8 (10

.

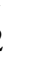

3

4

15

6
.

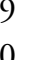


OMC will be in terms of strengthening cooperation and coordination across Member States in organ donation and transplantation policy. The danger remains that using OMC may add a significant administrative burden at national level, notwithstanding the Commission's claims to the contrary.

\section{The EU's Action Plan on Organ Donation and Transplantation (2009- 2015)}

Taking on board institutional, stakeholder and expert feedback, the Commission published a further Communication and Impact Assessment in December 2008, as well as a proposal for a framework Directive. This Communication set out a revised and more detailed action plan. It confirmed that increasing organ availability, enhancing the efficiency and accessibility of transplantation systems and improving the quality and safety of organs for transplant remained the main challenges to be addressed at EU level and ten priority actions were identified in order to address such challenges. It also confirmed that such priority actions would be addressed in the context of pursuing strengthened cooperation between Member States. The OMC methodology would be used to facilitate the identification and development of common objectives and guidelines, jointly agreed indicators and benchmarks, regular reporting, and identification and sharing of best practices. The Commission emphasised that it was a matter for Member States how best to achieve these objectives. ${ }^{23}$ In the following sections, I identify key issues which have emerged from the Commission's current action plan.

\subsection{Increasing Organ Availability}

Priority Actions 1 to 5 in the Commission's current action plan aim to address the challenge of increasing organ availability throughout the EU, focusing in particular on increasing rates of deceased organ donation at national level. ${ }^{24}$ The importance accorded to increasing organ availability reflects the fact that the ongoing shortage of organs remains the key issue structuring governance initiatives in the field, with more than 56,000 patients on waiting lists within the EU, with many dying while waiting for a suitable organ to become available. ${ }^{25}$ Priority Action 1 focuses on the need to appoint transplant donor coordinators (TDCs) in every hospital where there is potential for organ donation. This is in addition to devel-

12(4) (2006), 496; V. Hatzopoulos, "Why the Open Method of Coordination is Bad for You: A Letter to the EU”, European Law Journal 13(3) (2007), 326).

23) Commission of the European Communities. Communication. 8.12.2008, supra, n. 2, 2-3.

24) Priority Action 5 focuses on the need to take action to identify potential organs donors, as well as the potential for cross-border donation, within the EU. The Commission provides little in the way of detail, however, regarding what specific work will be done to realise this action. It is for this reason that it is not examined further in this paper (see Ibid., 5, 10).

25) Commission of the European Communities. Communication. 8.12.2008, supra, n. 2, 3. 
oping internationally-recognised standards, effective training and international 1 accreditation for TDCs.

The appointment of TDCs in every hospital where organ donation is an option 3 has been identified as a key element in increasing the rate of (deceased) organ 4 donation at national level. Spain enjoys the highest rate of deceased organ dona- 5 tion in the EU (see Table 2), and much of its success has been attributed to the 6 use of TDCs who are predominantly physicians, with specialities in nephrology 7 or intensive care. They do not report to transplant teams, but rather to the hospi- 8 tal that employs them, in addition to regional and national transplant organisa- 9 tions. They are provided with ongoing and intensive training in all aspects of 10 organ donation and transplantation activity and their work is seen as making the 11 difference between success and failure with respect to increasing the rate of 12 (deceased) organ donation. ${ }^{26}$ In other Member States, such as the UK, TDCs are 13 employed by, and therefore answerable to, local hospitals. It was recognised that 14 insufficient systemic or logistical support was provided to them, thus hampering 15 their ability to identify potential opportunities for organ donation. Drawing 16 inspiration from the Spanish model, reforms are currently being implemented 17 which recognise their importance to the success of the national organ procure- 18 ment programme. ${ }^{27}$ Support for this type of reform will no doubt be reinforced 19 through the EU's action plan.

The need to promote quality improvement programmes in every hospital where there is potential for organ donation is identified in Priority Action 2 as key to realising the objective of increasing organ availability. This action draws on a previously-adopted Recommendation by the Council of Europe in this area, ${ }^{28}$ and is designed to promote a self-evaluation process of organ donation operating in the context of national health systems, which is to be jointly performed by specialists in intensive care and TDCs in every hospital where there exists a potential for organ donation. The aim of the evaluation process is to identify best practices across Member States, which would then inform the design and implementation of appropriate methodologies for quality improvement programmes. ${ }^{29}$

The promotion of living organ donation programmes has been identified as Priority Action 3. In developing such programmes, the focus is on promoting altruistic donation, the development of best practices, and the creation of national registries to hold data on living organ donors. Living organ donation currently represents $17 \%$ of kidney transplant activity in Europe and includes the donation

26) R. Matesanz, and B. Dominguez-Gil, "Strategies to optimize deceased organ donation", Transplantation Reviews 21 (2007), 182.

27) Department of Health, Organs for Transplant: A Report from the Organ Donation Taskforce (London: Department of Health, 2008), 13-15.

28) Council of Europe. Recommendation Rec (2006) 16 of the Committee of Ministers to Member States on the Quality Improvement Programmes for Organ Donation (adopted 8 November 2006).

29) Commission of the European Communities. Communication. 8.12.2008, supra, n. 2, 4, 9.

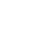
(1) ? 西 ) 0 1 2 3 4 15 6 
of kidneys, lobes of lungs, as well as portions of the liver, pancreas and intestines. The extent to which reliance is placed on this form of donation varies widely, however, with a very low rate in Spain of 2 transplants per million population (pmp) to a rate of 20.7 pmp in countries such as Norway. ${ }^{30}$ In identifying this area as a priority action, the Commission has recognised that there is a need to gather data on the medical, psychological, financial and social consequences following on from donation of organs by living donors, as well as to record any risk factors or other health problems experienced by living organ donors posttransplant. ${ }^{31}$

What the action plan does not formally acknowledge in prioritising this area of organ donation and transplantation is the significant degree of debate in relevant expert and policy communities over the merits (or otherwise) of living organ donation. It has been argued that living organ donation programmes should be promoted as a successful way of addressing the chronic shortage of organs available for transplantation, which is not currently addressed by deceased organ donation. As such, it should be promoted in line with agreed medico-scientific guidelines and/or regulatory frameworks. The adoption of this approach in North America has seen a substantial increase in the rate of living organ donation over the last ten to fifteen years, with transplant teams accepting donations from both genetically-related and non-genetically related donors, provided that there is informed consent and no material gain from the process of organ donation..$^{32}$ In the case of Member States such as the UK, for example, a national regulatory authority oversees cases of living organ donation and transplantation in line with framework legislation and more detailed guidelines provided in a supporting code of practice..$^{33}$

For others, living organ donation raises troubling ethical and human rights' issues. It has therefore been argued that if living organ donation is to be permitted at all, then it should be limited to those with a genetic or spousal relationship with the potential organ recipient, so as not to offend the principle against the instrumentalisation of human beings, whether for financial gain or some other comparable advantage. ${ }^{34}$ In addition, concerns have been raised about whether

30) Commission of the European Communities. Commission Staff Working Document accompanying the Proposal for a Directive of the European Parliament and of the Council on standards of quality and safety of human organs intended for transplantation and the Communication from the Commission. Action Plan on Organ Donation and Transplantation (2009-2015): Strengthened Cooperation between Member States: Impact Assessment. SEC (2008) 2956. Brussels, 8 December 2008, 17.

31) Commission of the European Communities. Communication. 8.12.2008, supra, n. 2, 4, 9-10.

32) L. Wright, "Ethical Controversies in Public Solicitations for Organs", Transplantation Reviews, 22 (2008), 184-186.

33) The Human Tissue Authority is the regulatory authority empowered to oversee living organ donation and transplantation in England under sections 33 and 34 of the Human Tissue Act 2004, c. 30. Its responsibilities in this regard are further elaborated upon in its Code of Practice 2: Donation of Solid Organs for Transplantation, paragraphs 26-92.

34) H.D.C., Roscam Abbing, "A Council of Europe Protocol on Transplantation of Organs and Tissue of 
the rise in living organ donation will undermine efforts to increase deceased organ 1 donation. The latter form of donation represents no risk to the donor, whereas 2 the same cannot be said for living organ donors, as there are recognised risks of 3 complications and/or death arising from the procedure. ${ }^{35}$ Finally, ethical concerns 4 have been raised about the fact that organ donation by a living donor involves the 5 performance of risky medical procedure, which is of no direct therapeutic benefit 6 to the individual in question. ${ }^{36}$ It is to be hoped that the Commission ensures that 7 account is taken of such ethical concerns in undertaking work on promoting living organ donation programmes.

Priority Action 4 focuses on the need to improve the knowledge and communication skills of health professionals and patient support groups on organ transplantation in seeking to increase organ availability. Specific activities to be taken in relation to this priority action include developing strategies to make better use of mass media and improve public education about organ donation and transplantation. This would involve ensuring that there is a systematic and comprehensive approach to the dissemination of information about organ donation and transplantation through media outlets, and would include regular meetings with journalists and national opinion leaders. In this regard, a systematic media campaign of this kind in Spain was found to have created a positive societal atmosphere around supporting organ donation and transplantation. ${ }^{37}$

In a Eurobarometer survey conducted in 2006 on the issue of organ donation, it was found that $41 \%$ of those polled stated that they had discussed the matter with their family, although there was a wide variation between countries ranging from $75 \%$ in the Netherlands to $24 \%$ in Austria. One of the conclusions from the survey was that public education about the processes of organ donation and transplantation was very important in terms of promoting organ donation after death. ${ }^{38}$ The findings from the Eurobarometer survey, however, do not correlate well with the rate of family refusals to consent to organ donation in relation to a deceased family member (see Table 1). It has been suggested that while there may be broad public support in principle for deceased organ donation, the reality of

Human Origin" European Journal of Health Law 9 (2002), 67. It is important to note that Article 10 of the Additional Protocol to the Convention on Human Rights and Biomedicine Concerning Transplantation of Organs and Tissues of Human Origin, Strasbourg, 24.I.2002, states that 'organ removal from a living donor may be carried out for the benefit of a recipient with whom the donor has a close personal relationship as defined by law, or, in the absence of such relationship, only under the conditions defined by law and with the approval of an appropriate independent body'.

35) The risk of a serious, but not life-threatening complications, for living organ donors, has been estimated to be $1-2 \%$. The mortality risk has been calculated at 1:3000 (see Commission of the European Communities. Impact Assessment. 30.5.2007, supra, n. 11, 31).

36) R. Truog, "The Ethics of Organ Donation by Living Donors", New England Journal of Medicine, 353(5) (2005), 444-446.

37) Ibid., $5,10$.

38) Europeans and Organ Donation Report. Special Eurobarometer 272D/Wave 66.2 - TNS Opinion and Social (May 2007), 5, 9.

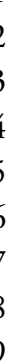


dealing with organ donation during a time of great emotional distress and bereavement makes decision-making for families much more difficult. Research has shown that at such time, families become concerned about how and in what circumstances the diagnosis of death is made, as well as seeking to protect the body of their deceased family member from being dissected or otherwise 'cut up'. In many cases this accounts for families' refusals to permit organ donation, notwithstanding the fact that the deceased family member may have held positive views about organ donation during her or his lifetime. ${ }^{39}$ This means that simply suggesting that more and better public education about organ donation and transplantation on its own will not necessarily lead to higher rates of organ donation, and therefore a more nuanced and differentiated approach to the delivery of public education is needed. ${ }^{40}$

Table 1. Family Refusal Rates for Deceased Organ Donation in Selected EU Member States*

\begin{tabular}{cc}
\hline Member States & $\begin{array}{c}\text { Family Refusal Rates } \\
\text { (\% rate per persons per million population (pmp)) }\end{array}$ \\
\hline Bulgaria & 80.0 \\
Estonia & 32.0 \\
Greece & 33.5 \\
Hungary & 7.4 \\
Ireland & 22.9 \\
Italy & 32.6 \\
Latvia & 54.2 \\
Lithuania & 31.2 \\
Poland & 10.9 \\
Romania & 28.7 \\
Spain & 15.2 \\
United Kingdom & 38.1 \\
\hline
\end{tabular}

* Source: Council of Europe (2009) TRANSPLANT: International Figures on Organ Donation and Transplantation 2008, Vol. 14(1): 38.

13
14
15
16
17
18
19

\footnotetext{
39) and J. Addington-Hall "Conflict Rationalization: How Family Members Cope with the Diagnosis of Brain Death", Social Science \& Medicine, 67 (2008), 253-261; M. Sque, T. Long,., S. Payne and D. Allardyce, "Why Relatives Do Not Donate Organs for Transplants: 'Sacrifice' or 'Gift of Life'?”, Journal of Advanced Nursing, 61(2) (2008), 134-144.

40) M. Levitt, "Educating the Public to Encourage Organ Donation?" in A.M. Farrell, D. Price, M. Quigley, (eds.), Organ Shortage: Ethics Law and Pragmatism (Cambridge: Cambridge University Press, 2010), forthcoming.
} 


\subsection{Enhancing the Efficiency and Accessibility of Transplant Systems}

Enhancing the efficiency of national transplant systems through implementing 2 optimal organisational structures and other arrangements is seen as a key factor in 3 meeting the challenge of increasing organ availability. Drawing on a range of data 4 and research sources, the Commission has identified significant variation in rates 5 of organ donation and transplantation activity in Member States, concluding that 6 certain organisational models performed better than others in terms of increasing 7 organ availability. Priority Actions 6 to 9 in the current action plan are therefore 8 focused on 'identifying the most efficient systems, sharing experiences and promoting best practices in the area. ${ }^{41}$ Priority Action 6 is specifically focused on enhancing national organisational models of organ donation and transplantation. This will require Member States to develop their own national priority actions in relation to improving their national and/or local organisational models. This will then provide a basis for subsequent evaluation and improvement, which will be facilitated through peer review at EU level. Consideration will also be given to making use of EU structural funds to assist in the development of national transplant systems in specific Member States where this may be necessary, as well as promoting networks of centres of reference on best practices. ${ }^{42}$

In terms of work that has already been done in relation to enhancing the efficiency of transplant systems, the Commission will be able to draw on the work that has already been undertaken by the Council of Europe on this issue. The Council of Europe has long been active in the field of organ donation and transplantation, having established an expert advisory committee; ${ }^{43}$ adopted resolutions and recommendations on various ethical and policy issues; ${ }^{44}$ developed and updated quality and safety standards; $;{ }^{45}$ and published annual statistical data on organ donation and transplantation activity in its Member States. ${ }^{46}$ Its expert advisory committee recently published a European consensus document covering how best to enhance the efficiency of national transplant systems with a review to

41) Commission of the European Communities. Communication. 8.12.2008, supra, n. 2, 5.

42) Ibid., 5, 11.

43) The Committee of Experts on the Organisational Aspects of Co-operation in Organ Transplantation (SP-CTO) was established following the 3rd Conference of European Health Ministers in Paris in 1987. For further details of the work of the Committee. Retrieved 10 November, 2009 www.edqm.eu/en/ Organisation_Work_Programme-72.html.

44) Recommendations adopted by the Council of Europe have covered a wide range of aspects of organ donation and transplantation including xenotransplantation, the role and training of professionals working in the field, and organ trafficking. Retrieved 11 November, 2009 www.edqm.eu/en/Recommendations-74.html. Recent Resolutions have focused in particular on aspects of living organ donation and transplantation. Retrieved 11 November, 2009 www.edqm.eu/en/Background-amp-Missions-67.html. 45) Council of Europe. Guide to the safety and quality assurance for organs, tissues and cells. 3rd edition and Addendum 2009, Strasbourg: Council of Europe Publications, 2009.

46) The most up-to-date published data on organ donation and transplantation in the Council of Europe's Member States can be accessed via the Transplant Newsletter International Figures on Organ Donation and Transplantation - 2008. 14 (1), September 2009. Retrieved 11 November, 2009 www.edqm.eu/en/ Background_Missions-67.html.

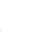
西 (1) 6 8

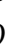


improving rates of organ donation. ${ }^{47}$ Such document relies to a great degree on what has become known as the Spanish model of organ procurement, which has resulted in Spain achieving the highest rate of deceased organ donation in Europe (see Table 2).

Key features of the model include the establishment of a transplant coordination network which operates at local, regional and national levels; continuous audits of potential organ donation opportunities through brain deaths and donation through intensive care units; a central administrative agency that coordinates and supports all the processes of organ donation; ongoing training of healthcare professionals involved in all aspects of organ donation and transplantation; the establishment of a reimbursement system for hospitals engaged in organ procurement; and the design and implementation of media and education campaigns to present information and a positive approach to organ donation. ${ }^{48}$ The Spanish model has provided the basis for the adoption of more efficient systems of organ procurement in Tuscany, Italy, as well as in several countries in Latin America. ${ }^{49}$ It has also recently been the subject of detailed study by UK policy-makers who have identified enhanced efficiency resulting in higher rates of organ donation as being associated with the implementation of optimum organisational arrangements for organ procurement. ${ }^{50}$

The need to establish commonly-agreed rules and structures to promote greater cross-border exchange of organs between Member States is identified as Priority Action 8. A number of cross-border organ exchange organisations already exist within Europe, including Eurotransplant, Scandiatransplant and Balttransplant. Eurotransplant is responsible for the mediation and allocation of organ donation procedures in Austria, Belgium, Germany, Luxembourg, the Netherlands and Slovenia. Participants in this supranational organisation include hospitals specialising in organ donation and transplantation, as well as tissue-typing laboratories. Scandiatransplant is the Nordic organ exchange organisation covering five countries, namely Sweden, Norway, Finland, Denmark and Iceland. Balttransplant facilitates organ exchange between the Baltic states of Estonia, Latvia and Lithuania. In addition, UK Transplant operates cross-border organ exchange between the UK and Ireland. ${ }^{51}$ While the work done under Priority Action 8 aims to build

\footnotetext{
47) Council of Europe. Organ shortage: current status and strategies for improvement of organ donation - $A$ European consensus document. Retrieved 11 November, 2009 www.edqm.eu/medias/fichiers/Organ shortagecurrent_status_and_strategies_for_improvement_of_organ_donation_A_European_consensus_ document.pdf.

48) R. Matesanz, and B. Dominguez-Gil, supra, n. 26, 181; see also R. Matesanz, and B. Miranda, "A Decade of Continuous Improvement in Cadaveric Organ Donation: The Spanish Model", Journal of Nephrology 15(1) (2002), 22-28.

49) R. Matesanz, and B. Dominguez-Gil, supra, n. 26, 185-186.

50) Department of Health, Organs for Transplant: A Report from the Organ Donation Taskforce. London: Department of Health, 2008, pp. 42-45.

51) Commission of the European Communities, Impact Assessment Accompanying Communication. 30.5.2007, supra, n. 11, 38.
} 
Table 2. Deceased Organ Donation Rates in EU Member States*

\begin{tabular}{cc}
\hline Member States & $\begin{array}{c}\text { Deceased Organ Donation Rate } \\
\text { (\% rate persons }\end{array}$ \\
\hline per million population)
\end{tabular}

* Source: Council of Europe, TRANSPLANT: International Figures on Organ Donation and Transplantation 2008, 14(1) (2009), 27-29.

on work already being done by these regional organisations, the Commission has identified that there is significant potential for the rate of cross-border exchange to be increased, offering greater scope for difficult-to-treat and urgent patients, as well as ensuring efficient distribution of any surplus organs in a particular Member State. ${ }^{52}$

52) Commission of the European Communities. Communication, 8.12.2008, supra n. 2, 6,11-12. 
What is surprising about the Commission's approach to this issue is that there has been little in the way of acknowledgement, let alone detailed examination, of the broader issues that should be taken into account in determining what should constitute just and fair criteria for the allocation and/or exchange of organs on an EU-wide basis in relation to all patients, not just the specific categories identified by the Commission. Allocation criteria for organs are clearly applied at national level, as well as through existing regional organ exchange organisations. In terms of work to be done in relation to this priority action, it is important that the Commission ensures that just, fair and transparent criteria and procedural requirements are in place with regard to cross-border allocation of organs. ${ }^{53}$

In the wake of feedback received from consultations with national experts, the Commission has also recognised the importance of promoting EU-wide agreements on important areas of transplantation medicine under Priority Action 7. These include patient mobility for treatment within the EU; the treatment of patients from outside the EU; the monitoring of organ trafficking; and agreed priorities and strategies for future research programmes. ${ }^{54}$ Although the issue of organ trafficking is not specifically identified as a priority action by the Commission in its action plan, it has underlined the importance of developing a common approach between Member States in relation to dealing with the problem. Notwithstanding concerns expressed by experts, stakeholders and EU institutions, one of the problems that the Commission has experienced to date has been in gathering data on the nature and extent of the problem of organ trafficking in the EU context.

In recent years, the Council of Europe has taken the lead in this regard, publishing a report and adopting a recommendation on ethical and legal issues raised by 'transplant tourism' and organ trafficking. ${ }^{55}$ It also endorsed the Declaration of Istanbul adopted at an international summit held in 2008, which condemns unethical activities facilitated by organ trafficking whilst at the same time acknowledging that strategies which increase organ availability to meet growing demand offers the best way forward for dealing with the problem. ${ }^{56}$ It remains to be seen

\footnotetext{
53) Roscam Abbing, supra n. 34, 66-67; S. Gevers, "Editorial: A Fair Distribution of Organs for Transplantation Purposes: Looking to the Past and the Future", European Journal of Health Law 14 (2007), 216-217; see also Article 3, Additional Protocol to the Convention on Human Rights and Biomedicine Concerning the Transplantation of Organs and Tissues of Human Origin (Strasbourg 24.I.2002), which states that in the case of international organ exchange agreements, the procedures must also ensure justified, effective distribution across the participating countries in a manner that takes into account the solidarity principle within each country'.

54) Commission of the European Communities. Communication (8.12.2008), supra n. 2, 6, 11.

55) R.-G. Vermot-Mangold (Rapporteur). Trafficking in Organs in Europe. Report to the Social, Health and Family Affairs Committee. Doc 9822. 3 June 2003. Retrieved 18 November, 2009 http://assembly. coe.int//Main.asp?link=http://assembly.coe.int/Documents/WorkingDocs/doc03/EDOC9822.htmCouncil of Europe. Recommendation 1611(2003) Trafficking in Organs in Europe. Retrieved 18 November, 2009 http://assembly.coe.int/Main.asp?link=/Documents/AdoptedText/ta03/EREC1611.htm.

56) The Declaration of Istanbul on Organ Trafficking and Transplant Tourism (2008) Retrieved 11 November
} 
what further action will be taken in this regard by the Commission in conjunc- 1 tion with Member States on this issue. At a recent meeting held with national 2 experts, it was noted that the experts considered the issue was currently being 3 adequately addressed by the Council of Europe and therefore was not a priority 4 in terms of EU action. . $^{57}$

In relation to promoting EU-wide agreements on a range of issues involving transplant medicine, the Commission will be able to draw on the knowledge and experiences of a range of European organisations and networks in the field. In 2004, the European Transplant Network (ETN) was established in line with the Prague Declaration which was signed by the Ministers of Health from new accession states to the European Union, as well as long-standing Member States such as Austria, Italy and Greece..$^{58}$ The ETN operates as an official intergovernmental organisation promoting mutual cooperation and information exchange on issues related to organ (and tissue) donation and transplantation, which is seen as particularly important given members' differing levels of infrastructural development of organ procurement and transplantation. The European Organ Exchange Organizations (EOEO) was also established in 2004 and brings together national and supranational organ procurement and exchange organisations that operate in Europe. The EOEO focuses on developing standards for quality, safety and traceability involved in the procurement and exchange of organs for transplantation. ${ }^{59}$

Key professional organisations include the European Society for Transplantation (ESOT) and the European Transplant Coordinators Organization (ETCO). ESOT was originally founded in 1982 at a meeting of transplant surgeons and it currently hosts a range of expert groups, as well as providing training, education and support in transplant medicine and research. ETCO was established in 1983 to represent those working as transplant coordinators throughout Europe, and to focus on strategies for enhancing organ procurement, particularly in terms of dealing with organ donors and their families. Key stakeholder organisations include the recently-created stakeholder platform, ELPAT, which is aligned with ESOT. ELPAT aims to promote communication exchange between academics, healthcare professionals, patient advocates and policy-makers at European level on ethical, legal and psycho-social issues involving organ donation and

2009 www.edqm.eu/medias/fichiers/The_Declaration_of_Istanbul.pdf; Steering Committee of the Istanbul Summit "Organ Trafficking and Transplant Tourism and Commercialism: the Declaration of Istanbul”, The Lancet 372 (2008), 5-6.

57) Commission of the European Communities. Experts Meeting on Organ Donation and Transplantation Action Plan: Summary Report. 11-12 March 2009, 5. Retrieved 20 November 2009 http://ec. europa.eu/health/ph_threats/human_substance/keydo_organs_en.htm.

58) The current members of the European Transplant Network are Italy, Austria, Cyprus, Czech Republic, Estonia, Greece, Hungary, Ireland, Italy, Latvia, Lithuania, Malta, the Netherlands, Poland and Slovakia.

59) Original members of the EOEO include national transplant organisations in France, Hungary, Italy, Poland, Portugal, Spain, Switzerland, the UK, as well as regional organisations Eurotransplant and Scandiatransplant. The relevant national organisation in the Czech Republic became a member in 2006.

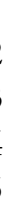
. ? 7 8 9 
transplantation. To this end, annual meetings and working groups dealing with specific issues in organ donation and transplantation have been formed. There are also a range of European umbrella organisations representing patients, including the European Kidney Patients' Federation, the European Heart and Lung Transplant Federation, Cystic Fibrosis Europe and Alpha One. These organisations recently formed the European Patients' Alliance for Transplantation (EPAT) to ensure more effective representation of their views in European policy-making processes. ${ }^{60}$

\subsection{Improving Quality and Safety}

The final two Priority Actions in the Commission's action plan aim to address the third main challenge of improving quality and safety. Priority Action 10 focuses on developing a methodology that provide the basis for establishing a common accreditation system for organ donation/procurement and transplantation programmes. ${ }^{61}$ Such system would feed into an EU-wide regulatory regime in the field, which will be discussed in more detail in the next section of the paper. Priority Action 9 is focused on developing a common approach to the evaluation of post-transplant results which will be supported by the creation of (a network of) registers to provide follow-up information on the health and well-being of organ recipients. In addition, there are plans to develop a common approach to determining what constitutes an acceptable level of risk in relation to the use of what has been described as 'expanded' or 'marginal' donors. The expectation of the Commission is that such activities will lead to the development of best (medical) practices in these areas.

The development of a common EU-wide approach to evaluating post-transplant results involving organ recipients is to be welcomed, particularly in relation to follow-up on the health of recipients at regular time intervals following transplantation. ${ }^{62}$ This may also help to identify the extent to which re-transplantation becomes necessary, as well as examining post-transplant outcomes resulting from the broadening of categories of donation, including expanded criteria donation (ECD) and non-heart-beating donation (NHBD). ${ }^{63}$ Although it has been argued that the use of these types of organs should be considered only in exceptional cases, ${ }^{64}$ there has been growing support by those working in transplant medicine for the increased use of ECD organs in recent years. It is recognised in the EU

\footnotetext{
60) For further details, see http://www.ceapir.org/wb/pages/ceapir/activities/epat.php.

61) Commission of the European Communities. Communication, 8.12.2008, supra, n. 2, 8, 12-13.

62) Ibid., 7, 12.

63) The other term that is commonly used to describe this category is donation after cardiac death.

${ }^{64)}$ It has been suggested that the use of ECD organs should only be contemplated in exceptional cases, in the context of the individual doctor and patient relationship, see Roscam Abbing, supra, n. 34, 65-66.
} 
context, however, that further work is needed on definitions, specific categories as well as follow-up on recipients who receive such organs. ${ }^{65}$

In recent years, for example, ECD organs have been used from deceased donors who were over the age of sixty years. In the case of kidney transplants, ECD organs have been used where there has been a history of hypertension or where stroke was the cause of death. Other instances involving the use of ECD organs have included those where the donor was infected with Hepatitis B and where the donor had a history of cancer. In accepting the use of ECD organs, it has been recognised that the outcomes achieved by recipients post-transplant are likely to be less successful than those where a standard compatibility match was achieved as between donor and recipient. ${ }^{66}$ Given that a potential recipient with end-stage renal failure may be facing imminent death, however, it has been argued that even given the prospect of a less than optimum outcome, ECD organs need to be considered where they may represent a life-saving option, at least in the short to medium term. In the circumstances, transplant clinicians have focused on reducing as much as possible the differences in outcome between standard and ECD organ donation post-transplant. ${ }^{67}$

Although NHBD is sometimes included in the ECD category, it is considered separately for present purposes given the particular ethical and legal problems it is likely to raise within the EU context. NHBD occurs where there is a diagnosis of death based on cardiopulmonary rather than neurological criteria (e.g. brain stem death), the latter diagnosis having achieved widespread ethical and legal acceptance as being necessary before deceased organ donation can take place. ${ }^{68}$ The vast majority of Member States (86\%) currently provide a statutory definition of brain stem death, with three Member States providing guidelines. The criteria used to establish brain stem death, however, vary widely as between Member States.

For example, the number of doctors required to diagnosis brain death ranges between two and four in Member States. ${ }^{69}$ This variability with regard to the diagnosis of death is also said to contribute to the failure to promote NHBD as a

\section{1} 2

\section{3} 4 5 6 7 8 9

65) Commission of the European Communities (DG Sanco). 2nd National Expert Meeting on Organ Donation and Transplantation, supra, n. 20, 3-4.

66) J. Pascual, J. Zamora and J.D. Pirsch, "A Systematic Review of Kidney Transplantation From Expanded Criteria Donors", American Journal of Kidney Disease 52(3) (2008), 553-558. For a detailed overview, see A. Cronin, "Making the Margins Mainstream: Strategies to Maximise the Donor Pool" in A.M. Farrell, D. Price and M. Quigley (eds.), Organ Shortage: Ethics Law and Pragmatism (Cambridge: Cambridge University Press, 2010), forthcoming.

67) V. Audard, M. Matignon, K. Dahan, P. Lang, and P. Grimbert, "Renal Transplantation from Extended Criteria Cadaveric Donors: Problems and Perspectives Overview”, Transplant International 21 (2008), $11-17$.

68) R.D. Truog, and F.G. Miller, "The Dead Donor Rule and Organ Transplantation”, New England Journal of Medicine, 359(7) (2008), 674.

69) Commission of the European Communities. Impact Assessment accompanying Communication. 30.5.2007, supra, n. 11, 26. 
category of potential organ donation. ${ }^{70}$ Further complications arise because only $45 \%$ of Member States have legislation and/or guidelines in place with respect to the definition and/or use of NHBD. ${ }^{71}$ This is so notwithstanding the development of the Maastricht criteria which elaborated on controlled and uncontrolled NHBD. ${ }^{72}$ Even with the publication of such criteria, however, ethical concerns remain among experts and other stakeholders over the diagnosis of death based on cardiopulmonary, rather than neurological, criteria. ${ }^{73}$

\section{The Proposed Organs Directive}

\subsection{Initial Consultation and Feedback}

When the Commission published its initial Communication in May 2007, it adopted a cautious note about the appropriateness of adopting a framework Directive in the field. The Commission acknowledged that the risk-benefit ratio in the case of organ donation and transplantation was fundamentally different to that involving other human material, such as blood and tissue, and this would need to be taken into account in drafting any proposal for a Directive. Having adopted such a cautionary note, however, the Commission went on to conclude that 'an appropriate and flexible' EU-wide regulatory regime was possible which would establish a 'basic quality and safety framework'. It intimated that it intended to follow a similar format to the one adopted in the earlier Blood and Tissues and Cells Directives, albeit with some changes to take account of specific issues affecting organ donation and transplantation. ${ }^{74}$ It was clear, however, that the Commission viewed the adoption of a Directive in the field as something that would take place in the short term, rather than the long term.

There was a mixed reaction amongst EU and national institutions, as well as stakeholders and experts, to the Commission's plans to bring forward a framework Directive in the field. While there was general agreement that quality and safety issues were important in the context of organ donation and transplantation, concerns were expressed that as things stood, the proposed quality and safety

\footnotetext{
70) G. Koffmann and G. Gambaro, "Renal Transplantation from Non-Heart-Beating Donors: A Review of the European Experience”, Journal of Nephrology, 16(3) (2003), 334- 341.

71) Commission of the European Communities. Impact Assessment accompanying Communication. 30.5.2007, supra, n. 11, 26.

72) M.G.J. Snoeijs, E.L.W. van Heurn, W.N.K.A. van Mook, M.H. Christiaans and J.P. van Hooff, "Controlled Donation after Cardiac Death: A European Perspective", Transplantation Reviews, 21(4) (2007), 219.

73) It has been claimed that such ethical concerns 'have largely been resolved over the past decade' (Ibid., 225). However, for a contrary view, see D. Price, "Promoting Organ Donation: Challenges for the Future" in A.M. Farrell, D. Price and M. Quigley (eds.), Organ Shortage: Ethics Law and Pragmatism (Cambridge: Cambridge University Press, 2010), forthcoming.

74) Commission of the European Communities. Communication. 30.5.2007, supra, n. 14, 9-10.
} 
framework to be included in any proposed Directive was likely to be too stringent 1 and would therefore impose an unwanted administrative burden at national 2 level. With this in mind, national experts urged the Commission 'not to create 3 obstacles which would decrease transplantation activity'. ${ }^{75}$ The concerns expressed 4 by experts in relation to the proposed Directive were also echoed in the report of 5 the UK House of Lords European Union Committee. The Committee took note 6 of the likely adverse consequences at national level that might result from the 7 'gold-plating' of regulation at EU level. It recommended that the adoption of an 8 EU-wide regulatory regime in the field should remain flexible, in particular that 9 it should not interfere with the application of expert clinical judgement and 10 informed patient choice. ${ }^{76}$

\subsection{Overview of the Proposed Organs Directive}

In publishing its proposal for a proposed Organs Directive, the Commission has clearly attempted to take on board feedback received about the potential adverse consequences that could result from a rigid, prescriptive approach to risk regulation. At the time of its publication, the Commission suggested that its proposal should be viewed as complementary to the revised action plan, supporting and triggering the implementation of priority actions. It argued that the proposed Organs Directive aimed at setting minimum standards in relation to key aspects of organ donation and transplantation, without being too prescriptive. In adopting this approach, the Commission further argued that it would provide for sufficient flexibility on the part of Member States to adapt their existing national systems to the requirements of the new regulatory regime without too much 'red tape and administrative burden'. ${ }^{77}$

An examination of the proposed Organs Directive shows similarities, as well as differences, from earlier Blood and Tissues and Cells Directives that were adopted pursuant to the same competence. ${ }^{78}$ The earlier two Directives included standardsetting for quality and safety in a range of quality and safety in relation to various steps in the donor-recipient chain. ${ }^{79}$ Taking account of necessary differences due

75) Commission of the European Communities. 1st National Expert Meeting on Organ Donation and Transplantation at Community Level: Summary Report. Brussels, 13 July 2007. SANCO C6 EFZ/ges D (2007) 360346), 3. Retrieved 17 November 2009 http://ec.europa.eu/health/ph_threats/human_ substance/events_organs_en.htm.

76) House of Lords European Union Committee, Increasing the Supply of Donor Organs within the European Union, Volume 1: 17th Report of Session 2007-08. HL Paper 123 -I. London: The Stationery Office, 2008, 25-28.

77) EUROPA. Press Release, supra, n. 1.

78) Article 152(4)(a) EC, now Article 168(4)(a) TFEU.

79) In relation to the Blood Directive, quality and safety standards cover the collection, testing, processing, storage and distribution of human blood and its components. In relation to the Tissues and Cells Directive, such standards cover donation, procurement, testing, processing, preservation, storage and distribution. 1.
1
1

\section{,}

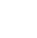

.

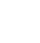

.


to the specificities of human organ donation and transplantation, this is also followed to some extent in the proposed Organs Directive with standard-setting for quality and safety in relation to the donation, procurement, testing, characterisation, preservation, transport and transplantation. ${ }^{80}$

The proposed Directive is divided into a number of chapters: subject matter, scope and definitions (Chapter I); the quality and safety of organs (Chapter II); donor and recipient protection (Chapter III); obligations of the competent authorities and exchanges of information (Chapter IV); exchanges of organs with third countries and European organ exchange organisations (Chapter V); general and final provisions (Chapters VI and VII). In the following sections, I examine key aspects of the proposed Directive, rather than attempting to cover each Article or Chapter in detail. It is also important to keep in mind that it is an examination of provisions of a proposed Directive in the field, and not an adopted text. Although the broad outline of key provisions in the proposal are likely to remain in the adopted text, there will no doubt be a range of amendment before the final text is agreed. Therefore, the examination of key aspects of the proposed Directive in the following sections needs to be viewed with this note of caution in mind.

\subsection{A Regulatory Framework for Basic Quality and Safety Requirements}

In the Explanatory Memorandum to the proposed Organs Directive, the Commission makes clear that the aim is to establish basic quality and safety requirements needed in every transplant system. ${ }^{81}$ One of the key provisions in this regard is the requirement that national quality programmes be established in line with 'standard operating procedures' across a range of specific areas. ${ }^{82}$ This term recurs on a regular basis throughout the proposed Directive. While it was used on occasion in the earlier Blood and Tissues and Cells Directives, ${ }^{83}$ it is defined for the first time in the proposed Organs Directive. It appears to allow for some degree of flexibility on the part of Member States in relation to meeting their obligations with respect to aspects of national quality programmes in areas such as verification procedures to be used for donor identity and donor consent, characterisation of donor organs, traceability of organs, the reporting of adverse events and the recall of organs. ${ }^{84}$ The importance for quality and safety purposes of an

\footnotetext{
80) Article 2(1), proposed Organs Directive, supra, n. 3.

81) Paragraph 17, Explanatory Memorandum, proposed Organs Directive, 4.

82) 'Standard operating procedures' means 'written instructions describing the steps in a specific process, including the materials and methods to be used and the expected end product' (Article 3(o), proposed Organs Directive).

83) Blood Directive, Annex 1, Part B (description of quality system); Tissues and Cells Directive: Article 16 (quality management); Article 20 (tissue and cell processing); Article 21 (tissue and cell storage).

84) Article 4, proposed Organs Directive, supra, n. 3.
} 
appropriate characterisation of organs is also emphasised with requirements as to 1 provision of information, testing and assessment by a qualified laboratory. ${ }^{85} \quad 2$

As was made clear in the Commission's action plan, organisational arrange- 3 ments are seen as crucial for enhancing organ availability and therefore addressing 4 the problem of chronic organ shortage at national level. To this end, Member 5 States are required to identify the organisational structure and operational pro- 6 cedures of their organ procurement organisations, including job descriptions, 7 accountability and reporting relationships. Key aspects of the organ procurement 8 are also required to be put in place, including the circumstances in which donor 9 selection takes place, the use of dedicated facilities, as well as the use of appropri- 10 ate personnel and operating theatres and equipment. ${ }^{86}$ Overseeing the authorisa- 11 tion of such organisations, as well as ensuring that they meet the required quality 12 and safety standards will be the responsibility of the designated competent author- 13 ity in individual Member States. ${ }^{87} \quad 14$

\subsection{The Protection of Donors and Recipients}

Key aspects of donor and recipient protection are dealt with in Chapter III of the proposed Directive. There are specific provisions relating to the protection of living organ donors which require that all necessary information be provided so as to enable them to make an informed decision about whether or not to donate. Selection requirements for living organ donation include an assessment by qualified healthcare professionals regarding their health and medical history, as well as a psychological evaluation if necessary. It also provides for the exclusion of organ donation by living donors on the grounds that the donation may present a (serious) health risk to potential recipients or themselves, particularly in the context of transmitting disease. ${ }^{88}$ Interestingly, no reference is made as to any specific limits or exclusions will be placed on the type of living organ donors based on their relationship (spousal, genetic, unrelated) to potential organ recipients. As previously discussed in this paper, this issue and the potential ethical conundrums it raises are clearly a matter of concern for the Council of Europe, as well as a range of other commentators. It will therefore be interesting to see whether or not amendments will be made to this Article as a result of inter-institutional negotiations over the final text of the Directive.

In addition, Chapter III also contains requirements concerning the protection of data collected on donors and recipients. Although it is recognised in the Commission's action plan that the collection of data on organ donation processes and

85) Article 7 and Annex, proposed Organs Directive.

86) Arts. 5-6, proposed Organs Directive.

87) For further details of the work to be done by the designated competent authorities in Member States, see Arts. 18-20, proposed Organs Directive.

88) Article 15, proposed Organs Directive.

\section{13
13
13
15}

10
1
13
14

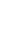

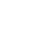

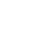

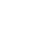

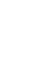

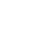

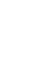

9
年

\section{5}


transplant outcomes is important for the purposes of facilitating further advances in transplant research and medicine, the proposed Directive also recognises the importance of protecting any personal data in line with relevant EU legislation ${ }^{89}$ as well as ensuring that all such data collected is anonymised, so as to prevent identification of donors and recipients. ${ }^{90}$ As EU-wide registries containing such data develop over time, it will be important for bodies such as the Commission to ensure that compliance with data protection legislation is in fact taking place. No doubt this can be facilitated through the provision of regular reporting on the part of Member States and the Commission on the implementation, which is likely to be included as a requirement in the adopted Directive. ${ }^{11}$

Principles governing organ donation include that both living and deceased organ donation should be voluntary and unpaid; that no financial gain or comparable advantage should be obtained from organ donation; and that the procurement of organs should be carried out on a non-profit basis. ${ }^{92}$ The promotion of altruism in organ donation and the prohibition on financial gain from such donation, is linked to broader ethical and human rights' principles regarding the need to uphold human dignity, as well as the need to prevent the instrumentalisation and/or commodification of human beings. Such principles derive normative legal support in the EU's Charter of Fundamental Rights ${ }^{93}$ and the Convention on Human Rights and Biomedicine, ${ }^{94}$ as well as in its Additional Protocol on the transplantation of human organs and tissue. ${ }^{95}$

While conceding the normative and legal force of these principles governing organ donation, a question needs to be raised as to whether such principles should provide the only basis on which organ donation should take place within the EU. The promotion of altruistic, non-remunerated organ donation has failed to address the growing shortage of organs and this persisting shortage results in thousands of individuals dying each year whilst on waiting lists. This ongoing human tragedy necessitates a more detailed examination of whether, and if so what, principled alternatives to altruistic, non-remunerated organ donation

\footnotetext{
89) Article 16; in particular, there should be compliance with 'Data Protection Directive' (see Directive 95/46/EC of the European Parliament and of the Council of 24 October 1995 on the protection of individuals with regard to the processing of personal of data and on the free movement of such data. OJ L 281/31. 23.11.1995).

90) Article 17, proposed Organs Directive, supra, n. 3.

11) Article 23, proposed Organs Directive.

92) Article 13, proposed Organs Directive.

93) As a result of the Lisbon Treaty coming into force on 1 December 2009, the Charter of Fundamental Rights now has legal force within the EU.

94) Convention for the Protection of Human Rights and Dignity of the Human Being with regard to the application of Biology and Medicine: Convention on Human Rights and Biomedicine. Oviedo, 4. IV.1997. Council of Europe: ETS No. 164. Retrieved 20 November 2009 http://conventions.coe.int/ Treaty/EN/Treaties/html/164.htm.

95) Additional Protocol to the Convention on Human Rights and Biomedicine Concerning the Transplantation of Organs and Tissues of Human Origin, supra, n. 34.
} 
should be considered. There is a wealth of academic and policy literature pub- 1 lished which examine alternative approaches to increasing the rate of organ dona- 2 tion, including permitting the sale of organs; ${ }^{96}$ establishing different types of 3 markets to facilitate payment for organs; ${ }^{97}$ and incentivising organ donation 4 through a range of financial measures. ${ }^{98}$ While it is outside the scope of this paper 5 to examine the merits (or otherwise) of these various positions on organ dona- 6 tion, it is disappointing in my view that the Commission chose not to examine 7 the diverse range of opinions and commentary on such alternative approaches, 8 given the current problems engendered by chronic organ shortage. ${ }^{99} 9$

In relation to regulatory requirements covering consent to organ donation, the 10 EU's competence to act on this issue is circumscribed by Article 168(7) TFEU, 11 which states that national provisions regarding the donation or medical use of 12 organs shall not be affected by the adoption of minimum harmonisation mea- 13 sures under Article 168(4)(a) TFEU. This limitation accounts for the reference in 14 the proposed Organs Directive to the requirement that 'procurement shall only 15 be carried out after compliance with all mandatory consent or authorisation 16 requirements in force in the Member State concerned'. ${ }^{100}$ As the Commission 17 makes clear in its supporting policy documentation, there is a degree of variation 18 as between Member States in relation to the consent regimes that have been 19 adopted in relation to deceased organ donation, reflecting the national specifici- 20 ties of historical, socio-cultural and medical contexts. ${ }^{101}$ The desire on the part 21 of Member States to ensure protection and political flexibility with respect to 22 national approaches on consent was no doubt a key factor in relation to the inclu- 23 sion of the limitation in Article 168(7) TFEU.

\footnotetext{
96) For example, A.S. Daar, "Paid Organ Donation - the Grey Basket Concept", Journal of Medical Ethics, 24 (1998), 365-368; J. Radcliffe-Richards, A.S. Daar, R.D. Guttmann, R. Hoffenberg, I. Kennedy, M. Lock, R.A. Sells and N. Tilney, (for the International Forum for Transplant Ethics), "The Case for Allowing Kidney Sales", The Lancet, 351 (1998), 1950-1952.

97) For example, see, L.A. Cohen, "A Futures Market in Cadaveric Organs: Would It Work?", Transplantation Proceedings, 1 (1993), 60- 61; C.A. Erin, and J. Harris, "An Ethical Market in Human Organs", Journal of Medical Ethics, 29(3) (2003), 137-138.

98) For an interesting recent examination of the ethical issues raised by offering a range of financial measures to incentivise organ donation, particularly from living donors, see G. Van Dijk and M.T. Hilhorst, Financial Incentives for Organ Donation: An Investigation of the Ethical Issues. Ethics and Health Monitoring Report 2007/3. Centre for Ethics and Health. The Hague, Council for Public Health and Health Care, 2007.

99) The Commission has acknowledged that 'there are many complex and sensitive ethical issues in this area... It is generally accepted that the donation should be voluntary and altruistic with legal and ethical contexts clearly defined, the data from donors and recipients should be protected, provided that traceability is ensured, except in the case of a living donor with a close relationship to the recipient', see Commission of the European Communities. Impact Assessment Accompanying Communication, 8.12.2008, supra, n. 30, 20.

100) Article 14, proposed Organs Directive, supra, n. 3.

101) Commission of the European Communities. Impact Assessment accompanying Communication, 30.5.2007, supra, n. 11, 24-27.
} 
Two types of consent regimes predominate in the EU context: an opt-in system which requires explicit consent from donors (e.g. donor card, donor registry) prior to death that they consent to organ donation; and an opt-out system where consent is presumed because donors do not object to organ donation during their lifetime, in circumstances where there are usually national guidelines and/or laws in place setting out how such objections can be made. This latter type of regime is more commonly referred to as one based on presumed consent. There are soft and hard variations of the scheme that have been adopted in relation to these two types of schemes. In the case of soft presumed consent regimes, it is still usual to consult with and/or seek the consent of families before organ donation involving their deceased family member takes place. ${ }^{102}$

Variations in consent regimes have also led to a lively debate in the academic and policy literature regarding what type of regime is likely to result in an increase in the rate of deceased organ donation. On the one hand, there are those who argue that a presumed consent regime is to be preferred, pointing to empirical research which shows a correlation between presumed consent regimes and higher rates of organ donation. ${ }^{103}$ Others challenge this argument, arguing that it is the organisational arrangements that are put in place with regard to organ procurement that are most likely to bring about higher rates of organ donation, and not the presumed consent regime on its own. ${ }^{104}$ This issue was recently the subject of national political debate in the UK with calls at senior government level for the introduction of a presumed consent regime as offering the best way forward for increasing the rate of deceased organ donation. ${ }^{105}$ Following further consideration of the issue, however, the government's key advisory body found that there was no convincing evidence that a change to a presumed consent regime would result in a significant increase in the rate of deceased organ donation in the UK. In the circumstances, it recommended that there be no change to the UK's current opt-in regime and that effort instead be focussed on improving organisational arrangements with respect to organ procurement. This approach was

\footnotetext{
102) S., Gevers, A. Janssen, and R. Friele, "Consent Systems for Post Mortem Organ Donation in Europe", European Journal of Health Law, 11 (2004), 176-177.

103) R.W., Gimbel, M.A. Strosberg, S.E. Lehrman, E. Gefenas, and F. Taft, "Presumed Consent and Other Predictors of Cadaveric Organ Donation in Europe", Progress in Transplantation, 13 (2003), 17-23; A., Abadie, and S. Gay, "The Impact of Presumed Consent Legislation on Cadaveric Organ Donation: A Cross-Country Study", Journal of Health Economics, 25 (2006), 599-620.

104) M. Quigley, M. Brazier, M. Navarro Michel and D. Paredes, "The Organs Crisis and the Spanish Model: Theoretical versus Pragmatic Considerations", Journal of Medical Ethics, 34 (2008), 223-224.

105) The calls were made by the senior medical adviser to the UK government: see Chapter 4, Chief Medical Officer, 2006 Annual Report of the Chief Medical Officer: On the State of Public Health (London: Department of Health, 2007). This was followed by the publication in a national newspaper of a letter from the UK Prime Minister, Mr. Gordon Brown which offered support for the change to a presumed consent regime in the UK: see Brown, Gordon . "Organ Donations Help Us Make A Difference", The Daily Telegraph, (14 January 2008).
} 
considered to offer the best chance of bringing about a 50\% increase in the rate 1 of organ donation over the next five years. ${ }^{106} 2$

\subsection{Cross-Border Organ Exchange 3}

As the Commission made clear in its current action plan, it sees definite added 4 value in EU action with regarding to promoting greater cross-border exchange of 5 organs. This was seen as particularly advantageous for smaller Member States 6 with limited donor pools, as well as in cases involving difficult-to-treat or urgent 7 patients. The proposed Directive provides for the establishment of basic quality 8 and safety requirements to facilitate cross-border exchange between Member 9 States and third countries, ${ }^{107}$ as well as between Member States themselves. On 10 this latter point, provided that there is compliance with the requirements of the 11 Directive, it is open to Member States to 'establish written agreements with Euro- 12 pean organ exchange organisations' in order to delegate to them the performance 13 of activities provided for under national quality programmes and specific tasks in 14 relation to cross-border exchange between Member States and third countries. ${ }^{108} \quad 15$ As previously discussed in this paper, a range of regional cross-border organisa- 16 tions and arrangements already exist within Europe. It is to be hoped that the 17 adoption of the Directive will facilitate not only greater cross-border exchange of 18 organs where appropriate, but that the Commission takes the lead in ensuring 19 that the allocation criteria for cross-border organ exchange is fair, just and 20 transparent.

\section{Adding Value? Matters for Concern}

The Commission's current action plan on organ donation and transplantation is 23 laudable in its aim, and ambitious with regard to its objectives. In relation to 24 some of the priority actions, however, there are indications that it is likely to be 25 too ambitious to achieve within the stated six-year lifespan of the action plan. The 26 minutes of the experts' meeting held following the publication of the action plan 27 revealed a narrowing of focus with regard to work to be done on priority actions, 28 with the creation of a technical working group on increasing the rate of deceased 29 organ donation, but the postponement of work on living organ donation for a 30 further two years. There also appears to be little current interest on the part of 31 experts in promoting a European awareness-raising campaign on organ donation, 32

\footnotetext{
106) Organ Donation Taskforce, The Potential Impact of An Opt Out System for Organ Donation in the UK: An Independent Report from the Organ Donation Taskforce. 17 November 2008, 34. Retrieved 20 November, 2009 www.dh.gov.uk/en/Publicationsandstatistics/Publications/PublicationsPolicyAndGuidance/DH_ 090312.

107) Article 21, proposed Organs Directive, supra, n. 3.

108) Article 22, proposed Organs Directive.
} 2

(1)
8 (1) 0

1

2

3

4

5

16

17

8


nor in taking any immediate action on issues related to organ trafficking. Concerns were also expressed that there was a risk of duplication of work already done by the Council of Europe in relation to establishing a common set of indicators and a methodology to monitor and evaluate organ donation and transplantation policy at national level. In response to such concerns, Commission staff claimed that this would not arise, as the work to be done in this area would be based on the findings from two EU funded projects in the area. ${ }^{109}$

The minutes of this recent experts' meeting raise a number of concerns about aspects of EU governance in organ donation and transplantation. First, it would be beneficial if the Commission could clarify exactly how it intends to make use of existing pan-European expertise in the field. This should be done in order to avoid the problem of duplication of effort resulting from work already done, particularly by experts working under the auspices of the Council of Europe. As has been previously discussed in this paper, EU governance in the field has not emerged in a pan-European vacuum. An existing 'epistemic community' of experts in organ donation and transplantation already exists who have long engaged in information-sharing and cross-national policy learning. ${ }^{110}$ Given limited national resources and personnel, it is incumbent on the Commission to draw on this body of knowledge and expertise in relation to the work to be done under its action plan.

The question of how the Commission proposes to integrate existing panEuropean expertise in the field also raises a broader point about the role of experts in emerging EU governance in the field of organ donation and transplantation. Most pan-European activity to date in the field has been driven through informal, non-legally binding arrangements devised by experts, operating in a largely technocratic environment. This is likely to change with greater EU involvement and activity in the field. There is likely to be a shift of power and influence away from such experts towards Member States, their political and institutional representatives and EU institutions, such as the Commission. In addition, the emerging EU policy community in organ donation and transplantation is likely to involve a wider array of actors and organised interests with potential to influence politics and policy-making processes in the field, than was previously seen at European level. The dynamics of policy-making in a multi-level governance environment is such that national experts will be one, albeit highly influential, group amongst a number of other stakeholder groups seeking to influence EU policy in the field. Having said that, their prominence is likely to be assured in the long term given that their input is essential for the drafting and implementation of technical aspects involved in policy and regulatory initiatives in the field.

\footnotetext{
109) Commission of the European Communities (DG Sanco). Experts Meeting on Organ Donation and Transplantation, supra, n. 57.

110) P. Haas, "Introduction: Epistemic Communities and International Policy Coordination", International Organization, 46 (1) (1992), 1-33.
} 
The timetable for the adoption of the Organs Directive, as well as its transposi- 1 tion into national law, is also a matter of concern. Given the ambitious objectives 2 of the Commission's action plan, differing levels of infrastructural development 3 regarding organ procurement in Member States, and questions regarding addi- 4 tional administrative burden at national level, it is unclear how an Organs Direc- 5 tive is likely to add value in the short term. Although the Commission claims that 6 a Directive would simply incentivise work already being done under the action 7 plan and would therefore be unlikely to add to the administrative burden at 8 national level, it is not clear that this will be the case. Unlike the action plan, a 9 Directive carries legally-binding obligations, which are required to be met within 10 a specified time-frame. As has become apparent in relation to the Blood and Tis- 11 sues and Cells Directives, substantial transaction costs and other unintended con- 12 sequences were incurred in relation to their implementation at national level, 13 particularly in the case of new accession Member States. ${ }^{111}$ As it stands, the broad 14 framework of the proposed Organs Directive is such that much work still needs 15 to be done by Member States in relation to fleshing out aspects of the quality and 16 safety framework. This begs the question as to whether this would be better done 17 under the work programme set out under the action plan. Subject to review at 18 regular intervals, a decision could then be taken to adopt an Organs Directive 19 once key aspects of the work programme are completed, particularly with regard 20 to embedding effective organisational arrangements involving organ procurement 21 at national level.

Another matter for concern is whether and, if so, how the Commission should deal with ethical issues in organ donation and transplantation that may give rise to conflict between experts, stakeholders and/or other EU institutions. On the one hand, it could be argued that ethical issues in the field are a matter for Member States, and that EU competence in the field is limited to undertaking activities designed to strengthen cooperation between Member States, as well as adopting minimum harmonisation measures involving standard setting for quality and safety. On the other hand, there are a range of ethical issues raised by aspects of organ donation and transplantation, such as living organ donation, the use of ECD organs, and organ allocation criteria to name but a few discussed in this paper, which should be taken into consideration in transplant medicine, as well as in the degree of legal protection that should be provided to both donors and recipients, in the EU context.

Indeed, the evidence from the fraught inter-institutional negotiations that took place in relation to the earlier Blood and Tissues and Cells Directives revealed the difficulties of attempting to separate out ethical issues from those related to risk in relation to the use of human material. While political compromises were

111) A.M. Farrell, "The Politics of Risk and EU Governance of Human Material", Maastricht Journal of European and Comparative Law”, 16(1) (2009), 51-54. 
achieved in both cases which enabled the adoption of the Directives, the failure to engage more fully with ethical concerns raised during the course of such negotiations was not a situation that was unlikely to engender public trust or confidence in the legitimacy of policy and regulatory processes in what is acknowledged to be a politically-sensitive area of governance at EU level. ${ }^{112}$ It would therefore be beneficial if the Commission clarified it proposes to deal with ethical aspects raised by transplant medicine and research and how this will in turn will feed into a principled approach to technical and regulatory processes associated with governance initiatives in the field.

What the negotiations over the final texts of the Blood and Tissues and Cells Directives also revealed was the problems created by having such a limited competence to act in relation to the governance issues that are raised by the use of human material. The political impetus for the creation of the competence originated in the political fall-out from HIV/AIDS blood contamination scandals at national level. ${ }^{113}$ In this context, the transfer of a limited competence to enable minimum harmonisation measures to be taken which established an EU-wide risk regulation regime to enhance blood safety made sense. The difficulties engendered by such a narrowly-circumscribed competence, however, became apparent in the case of the Tissues and Cells Directive and are perhaps even more so in the case of the proposed Organs Directive. ${ }^{114}$ A more differentiated approach to risk management is needed in this instance, given the chronic shortage of organs in most Member States and the fact that organ transplant represents the only lifesaving option for many patients. In the circumstances, a regulatory regime is needed that remains sufficiently flexible to allow for discretion in the exercise of clinical judgement and patient choice with regard to determining the acceptability of risks relating to organs which become available for transplantation. The Commission has sought to accommodate such difficulties by promoting a hybrid approach to EU governance in the field, combining new governance mechanisms, such as OMC, as well as more traditional command and control measures, such as those provided for under Article 168(4)(a) TFEU. ${ }^{115}$ Whether this will approach to governance will work efficiently and effectively in practice, however, remains to be seen.

\section{Conclusion}

This article examined recent developments in EU governance of organ donation and transplantation, in particular the Commission's current action plan and the

\footnotetext{
112) Ibid., 63-64.

113) A.M. Farrell, "Is the Gift Still Good? Examining the Politics and Regulation of Blood Safety in the European Union", Medical Law Review 14(2) (2006), 168.

114) A.M. Farrell, supra, n. 111, 60-61.

115) Ibid., 62.
} 
proposed Organs Directive. Such examination revealed that while there is much 1 potential for value-added action in the field at EU level, a number of concerns 2 remain. The action plan is ambitious and it is unclear whether the current time- 3 scale for meeting the main challenges set out in the plan is realistic, given the 4 scope of the planned work programme, differing levels of organisational develop- 5 ment of organ procurement at national level, and concerns over the extent to 6 which additional administrative burdens will be imposed by EU action given 7 limited national resources in the field. In addition, it would be beneficial if the 8 Commission clarified in its published policy documentation how it proposes to 9 build upon existing pan-European expertise in transplant research and medicine, 10 as well as how it proposes to deal with problematic ethical issues which are likely 11 to arise in the field. 12

While a Directive is to be welcomed in terms of establishing a basic quality and 13 safety framework, it is not clear that there is merit in its adoption and implemen- 14 tation in the short-term, given the demands imposed at national level by the work 15 programme set out in the action plan. The adoption of a Directive creates legal 16 obligations with regard to its transposition into national law and it may impose 17 significant transaction costs and raise particular resource difficulties for a number 18 of Member States. Time and effort could perhaps more efficiently and effectively 19 be spent in the short term on achieving priority actions in the action plan, par- 20 ticularly those relating to establishing optimum national organisational arrange- 21 ments with regard to organ procurement. Overall, EU action on organ donation 22 and transplantation should be viewed as a welcome development. Ultimately, the 23 added value of its governance initiatives in the field is likely to be measured by the 24 extent to which they successfully address the ongoing problem of organ shortage 25 in Member States. 
